\title{
Entrepreneurship Qualities of Member of Chamber of Commerce and Industries (CCI) of Nepal
}

\author{
Yam Bahadur Silwal ${ }^{1}$ \& Kamal Das Manandhar ${ }^{2}$ \\ ${ }^{1} \mathrm{PhD}$ Scholar of Mewar University, Rajasthan, India \\ ${ }^{2}$ Professor, Tribhuvan University, Kathmandu, Nepal \\ Corresponding Author \\ Yam Bahadur Silwal \\ Email: yamsilwal@gmail.com
}

\section{ABSTRACT}

Entrepreneurship is the capacity for innovation and caliber to introduce innovative techniques in the business operations whereas entrepreneurship quality is the professional application of knowledge, skills and competencies. Entrepreneurship qualities include the management skill, leadership skill, communication skill, decision making skill, creative and innovativeness, risk taking skill etc. the qualities come either by experience or by education and training. The study has focused to identify the entrepreneurship qualities of the member of chamber of commerce and Industries (CCI). The study is conducted in the four districts among the 400 respondent. The data was collected by using the structured questionnaire and collected data is analyzed through the statistical model. Factor analysis is done to present the data. The result shows that there are two major entrepreneurship quality factors: psychological and managerial factor. Each factor has three to four sub-qualities/variables. The study found the more importance of creativity \& innovativeness, hardworking, good management skill and decision making skill.

\section{KEYWORDS}

Chamber of Commerce and Industries (CCI), Entrepreneurship qualities, Managerial factor, Psychological factor

\section{INTRODUCTION}

The concept of entrepreneurship has a range of meanings. On the one extreme, an entrepreneur is a person of very high aptitude who pioneers change, possessing characteristics found in only a very small fraction of the population. On the other extreme of definitions, anyone who wants to work for him or herself is considered to be an entrepreneur (Forces, Porter's Five, 2010, p. 1). The 
word entrepreneur originates from the French word, entrepreneur, which means "to undertake." In a business context, it means to start a business. The Merriam-Webster Dictionary presents the definition of an entrepreneur as one who organizes, manages, and assumes the risks of a business or enterprise (Forces, Porter's Five, 2010, p. 1). Ganeshan stated that entrepreneurship is the capacity for innovation and caliber to introduce innovative techniques in the business operations (Ganeshan, 2001).The sociologists feel that certain communities and cultures promote entrepreneurship. Still, others feel that entrepreneurs are innovators who come up with new ideas for products, markets or techniques (Dhanak, 2017, p. 4). Entrepreneurship involves decision making, innovation, implementation, forecasting of the future, independency, and success first and this is how entrepreneurship developed (Dhanak, 2017, p. 4). A good decision maker can achieve the success in every step of life; they can convert the challenges into a good opportunity.

Entrepreneurship is a dynamic process of vision, change, and creation. It requires an application of energy and passion towards the creation and implementation of new ideas and creative solutions. Essential ingredients include the willingness to take calculated risks- in terms of time, equity, or career; the ability to formulate an effective venture team; the creative skill to marshal needed resources; the fundamental skills of building a solid business plan; and, finally, the vision to recognize opportunity where others see chaos, contradiction, and confusion (Dhanak, 2017, p. 4). 'Entrepreneurship is the professional application of knowledge, skills and competencies and/or of monetizing a new idea, by an individual or a set of people by launching an enterprise de novo or diversifying from an existing one (distinct from seeking self employment as in a profession or trade), thus to pursue growth while generating wealth, employment and social good' (Goswami, Dalmia, \& Pradhan, 2008). For Schumpeter, entrepreneurship resulted in new industries and in new combinations of existing inputs. Schumpeter's initial example of this was the combination of a steam engine and then current wagon making technologies to produce the horseless carriage. In this case, the innovation, the car was transformational but did not require the development of dramatic new technology. It did not immediately replace the horse-drawn carriage, but in time, incremental improvements reduced the cost and improved the technology, leading to the modern auto industry (Wikipedia, free encyclopedia, 2017, p. 3). Entrepreneurship can provide the solution by creating wealth, jobs, and social empowerment. If we are to address the issue of poverty with some degree of success, history tells us we have no choice but to actively encourage 
entrepreneurial ventures. In the Philippines, entrepreneurship is viewed as important to empowering the poor, enhancing production, and as an impetus to innovation (Evangelista, 2013).

In Nepalese context, CCI is one umbrella body of all entrepreneurs which works for the promotion, distribution, quality assurance and capacity building of entrepreneurs. CCI is established in district level to facilitate the program and problem of CCI's members. It organizes various programs focusing on the promotion of business sectors. It provides the capacity building training program to their member to build their entrepreneurship qualities. Entrepreneurship qualities cover the managerial capacity, leadership skill, interpersonal communication skill, decision making capacity, creative and high self-esteem. So, regarding the importance of entrepreneurship qualities, the study is going to identify the entrepreneurship qualities of a member of CCI of Nepal.

\section{MATERIALS \& METHOD}

The study is based on descriptive and exploratory research design. The study has explored the entrepreneurship qualities of the member of CCI members of Damak, Hetauda, Pokhara and Surkhet of Nepal. The study has collected the data from 400 members from the four districts. The sample size was calculated by considering the confidence level (95\%), prevalence (0.5) and margin of error (.05). The respondents were selected by using the simple random sampling technique. A structured questionnaire survey was done to collect the data. The statistical model like factor analysis, mean value and frequency are used to analyze the data.

Principal component analyses are done for factor analysis which is appropriate to measures on a number of observed variables and wishes to develop a smaller number of artificial variables (called principal components) that will account for most of the variance in the observed variables. The principal components may then be used as predictor or criterion variables in subsequent analyses. The factor loading value $=.5$ was considered and with eigen-value is 1.00 .

\section{RESULTS \& DISCUSSION}

Socio-demographic data shows that there was $85 \%$ male and $15 \%$ females participated in the study. The sex distribution indicates that there was a higher number of male participation in business sector than female. Similarly, caste wise, a higher number of Brahamin (33.8\%) and Chhetri (22.3\%) participated in the study. Very less number of Rai $(0.3 \%)$ and Limbu $(0.5 \%)$ involved in 
the study. It indicates the less participation of other ethnic communities in business sectors. The data shows the level of education of respondents that intermediate and graduate level education was equal (27.8\%) in number, whereas $4.8 \%$ were literate only and $4.3 \%$ were post graduate. The year of involvement of respondent in business sector was reported from 1 year to above 16 years and age wise minimum 16 years to 66 years with 43.63 mean age of respondent participated in the study.

\section{Factor loading of variables of entrepreneurship quality}

The following analysis presented in Table $\mathbf{1}$ is done for factor analysis which has given the significant value of KMO to ensure the eligibility of further analysis. The KMO value is .743 with $\mathrm{P}=.000$ significant level. The $\mathrm{p}$ value is less than .05 significant levels so that this data can be used for further analysis.

Table 1: Factor Analysis.

\begin{tabular}{|l|l|l|}
\hline \multicolumn{3}{|c|}{ KMO and Bartlett's Test } \\
\hline Kaiser-Meyer-Olkin Measure of Sampling Adequacy. & .743 \\
\hline \multirow{3}{*}{ Bartlett's Test of Sphericity } & Approx. Chi-Square & 1278.901 \\
\cline { 2 - 3 } & $\mathrm{df}$ & 78 \\
\cline { 2 - 3 } & Sig. & .000 \\
\hline \multicolumn{2}{|c|}{ Rotated Component Matrix } & \\
\hline Creativity and innovativeness & 1. Psychological factor & 2. Managerial qualities factor \\
\hline Confidence & .603 & \\
\hline High self esteem & .522 & \\
\hline Initiative taking abilities & 1.117 & .533 \\
\hline Management skill & .849 & .813 \\
\hline Decision making capacity & & 1.287 \\
\hline Flexibility & & \\
\hline
\end{tabular}

Source: Field Survey, 2016

The data was done the factor analysis by applying the principal component analysis method which divided the total variables into two major groups. The cut off value of factor loading was considered at .5; less than .5 was not included in the group as well as at least three variables were considered to be a group.

\section{Psychological quality factor}

From the factor analysis, the different variables of entrepreneurship quality are divided into two major factors considering the value of factor loading. One of the major quality factors is psychological quality factors which have covered the creativity and innovativeness, dignity for 
labor, high self-esteem and initiative taking abilities. The data presented in Table 2 shows that out of the total, $52.3 \%$ followed by $18.8 \%$ gave most important and more important respectively for the creativity and innovativeness as an entrepreneurship quality of an entrepreneur. The mean value is 1.8200 which is close to the more important level so, in totality, the response is positive. Creativity is one of the most important factors for the entrepreneur to think the business from the wider horizon. Creativity is a mental characteristic that allows a person to think outside of the box, which results in innovative or different approaches to a particular task.

Similarly, hardworking is one quality of a successful person. Nothing can be achieved in free of cost; without hard labor. So to be a successful entrepreneur, one should be laborious and hard working. Around $94 \%$ people have given the important value to the hardworking with 2.0575 mean values. The mean value is close to the more important. Similarly, around $56 \%$ has given importance to the high self-esteem also and around $70 \%$ has given important value to the initiative taking abilities also.

Table 2: Psychological quality factor.

\begin{tabular}{|l|l|l|l|l|l|l|l|}
\hline Questions & $\begin{array}{l}\text { Most } \\
\text { important } \\
(\%)\end{array}$ & $\begin{array}{l}\text { More } \\
\text { Important } \\
(\%)\end{array}$ & $\begin{array}{l}\text { Important } \\
(\%)\end{array}$ & $\begin{array}{l}\text { Less } \\
\text { Important } \\
(\%)\end{array}$ & $\begin{array}{l}\text { Not } \\
\text { important } \\
(\%)\end{array}$ & $\begin{array}{l}\text { Total } \\
(\%)\end{array}$ & Mean \\
\hline $\begin{array}{l}\text { Creativity and } \\
\text { innovativeness }\end{array}$ & 52.3 & 18.8 & 24.3 & 4.3 & 0.5 & 100 & 1.8200 \\
\hline $\begin{array}{l}\text { Dignity for } \\
\text { labor } \\
\text { (hardworking) }\end{array}$ & 30.3 & 40.5 & 23 & 5.8 & 0.5 & 100 & 2.0575 \\
\hline $\begin{array}{l}\text { High self } \\
\text { esteem }\end{array}$ & 19.5 & 16.3 & 20 & 30 & 14.3 & 100 & 3.0325 \\
\hline $\begin{array}{l}\text { Initiative } \\
\text { taking abilities }\end{array}$ & 20.3 & 15.5 & 34.8 & 28.8 & 0.8 & 100 & 2.7425 \\
\hline
\end{tabular}

Source: Field Survey, 2016

The mean value of high self-esteem and initiative taking abilities are 3.0325 and 2.7425 respectively which are close to the neutral value (just important) so these values show the comparatively less important of these two variables as an entrepreneurship quality. Though an entrepreneur should be creative, should have an innovative idea, should care the dignity of other and respect other. Respondent did not give more importance to the high self esteem to be a good entrepreneur. From the experience of respondents, over ambitious and over confidence is also not good for the entrepreneur. Entrepreneurs should enjoy what they do. They believe in themselves 
and are confident and dedicated to their project. Occasionally, they may show stubbornness in their intense focus on and faith in their idea. But the flip side is their demonstrated discipline and dedication (Ghosh, 2017). Self-confidence refers to the authority to arrive at one's own conclusions, to make decisions and to act (Buckingham \& Clifton., 2001).

Among the personal competencies that have been specified for entrepreneurial leaders, proactiveness, innovativeness, and risk-taking are the most cited ones that indicate entrepreneurial orientations at both personal and organizational levels (Chen, 2007; Kuratko D. , 2007; Gupta, MacMillan, \& Surie, 2004; Covin \& Slevin, 1991). Innovativeness is the ability and tendency of entrepreneurial leaders to think creatively and develop novel and practical ideas relating to opportunity recognition, resource utilization and problem solving (Gupta, MacMillan, \& Surie, 2004; Chen, 2007; Rae, 2007).

Hard work is the energy to work "every day" if necessary to achieve goals, which may include both working days and holidays (Buckingham \& Clifton., 2001). Self-discipline has two aspects: First, objectivity when administering the business to keep the personal finances apart from those of the business and second, the capacity to administer time which implies planning, organizing and carrying out activities in order of importance (Covey, 1997). The performance of business depends upon the honesty and hardworking of management and employee.

\section{Managerial quality factor}

Managerial quality is one of the major factors of entrepreneurship quality. The manager is one who can manage overall internal and external program of their assigned organization. There are three indicators under the managerial quality factor: management skill, decision making capacity and flexibility. The result presented in Table 3 shows that $93 \%$ gave important value to the management skill followed by $80 \%$ gave importance to decision making capacity and only $45 \%$ gave importance to the flexibility.

Table 3: Managerial qualities factor.

\begin{tabular}{|l|l|l|l|l|l|l|l|}
\hline Questions & $\begin{array}{l}\text { Most } \\
\text { important } \\
(\%)\end{array}$ & $\begin{array}{l}\text { More } \\
\text { Important } \\
(\%)\end{array}$ & $\begin{array}{l}\text { Important } \\
(\%)\end{array}$ & $\begin{array}{l}\text { Less } \\
\text { Important } \\
(\%)\end{array}$ & $\begin{array}{l}\text { Not } \\
\text { important } \\
(\%)\end{array}$ & Total & Mean \\
\hline $\begin{array}{l}\text { Management } \\
\text { skill }\end{array}$ & 29.3 & 32.8 & 31.0 & 6.3 & 0.8 & 100.0 & 2.1650 \\
\hline $\begin{array}{l}\text { Decision making } \\
\text { capacity }\end{array}$ & 26.8 & 17.5 & 35.8 & 18.3 & 1.8 & 100.0 & 2.5075 \\
\hline Flexibility & 17.0 & 11.0 & 19.0 & 27.0 & 26.0 & 100.0 & 3.3400 \\
\hline
\end{tabular}

Source: Field Survey, 2016 
The mean values are $2.1650,2.5075$ and 3.3400 of management skill, decision making capacity and flexibility respectively. The mean values are more close to the more important and important. The result indicates that management skill is given more importance than the decision making capacity and flexibility. There was a different opinion on the importance of flexibility skill of entrepreneurs. Flexibility in the sense that an entrepreneur can adopt the new techniques, can change their decision as the demand of time and can provide some flexibility to the employee also during the performance of work. There was variance in an experience of flexibility; some believe in autocratic leadership and some believe in democratic leadership so the response in flexibility is directed towards the important to less important.

An entrepreneur should have good management skill to manage the overall service quality and organizational performance. Customer satisfaction is the main goal of good management. Many previous kinds of literatures have given focus on the total quality management (TQM) for the better performance of an organization. Gilbert stated that a central principle of TQM is that mistakes may be made by people, but most of them are caused, or at least permitted, by faulty systems and processes. This means that the root cause of such mistakes can be identified and eliminated, and repetition can be prevented by changing the process (Gilbert, 1992). Total quality management (TQM) and entrepreneurial orientation (EO) have been among the most popular universal strategies for survival and growth of many organizations in the current competitive environment (El Shenawy, Baker, \& Lemak, 2007; Escrig-Tena, 2004; Kaynak, 2003; Reed, Lemak, \& Mero, 2000; Sila \& Ebrahimpour, 2000; Zahra, 1991; Zahra, Nielsen, \& Bonger, 1999).The increase of global competition, exacerbated by deregulation, has motivated organizations to adopt TQM (Total Quality Management) as a strategy to respond to customer requirements (Han, Chen, \& Ebrahimpour, 2007). TQM can be understood as a management philosophy, whose main concern is to meet the needs and expectations of customers through the integration of all functions and processes of the organization to achieve continuous improvement of quality of goods and services (Lenka \& Suar, 2008; Han, Chen, \& Ebrahimpour, 2007; Fuentes, Montes, \& Fernández, 2006).

Similarly, decision making skill is one of the important factors of the manager. Understand the role of entrepreneur gives a better insight about what competencies needed by entrepreneurs to ensure the survival of the business as well as business success. The role of decision makers is focusing on the development of entrepreneurial competencies (Ahmad, Halim, \& Zainal, 2010). 
An entrepreneurship should be flexible to adapt the new technology to increase the production and motivate the employee.

\section{CONCLUSIONS}

The factor analysis of total variables of entrepreneurship qualities is divided into two major components: psychological and managerial quality factor. The both factors have three to four variables. Psychological quality factor has covered the creativity \& innovative quality, hardworking, self-esteem and ability to take initiation. Similarly, managerial quality factor has covered the management skill, decision making capacity and flexibility. Under the psychological quality, respondent gave more importance to the creativity, innovative quality and hard working whereas they gave less importance to the self-esteem. An entrepreneur should be a creator of the new idea, should be a good planner to materialize the new idea and hardworking to achieve that new idea. The respondent gave the high importance to management and decision making skill of entrepreneurs than the nature of flexibility. CCI's member gave the mixed answer for flexibility as a quality of an entrepreneur. Some respondent marked the demerit of flexibility and some marked the benefit of flexibility. But it is true that an entrepreneur should be democratic by nature to get the support of employee and public participation.

The study has given the new insight of entrepreneurship quality of Nepalese entrepreneurs. All these qualities should be gradually enhanced to extend the size of the market of product and service and important to improve the quality of service. From the study, respondent shared the role of CCI to build the entrepreneurship quality of entrepreneurs so it is necessary to explore the role of CCI for the development of entrepreneurship quality of Nepalese entrepreneur in future research.

\section{REFERENCES}

Ahmad, N., Halim, H., \& Zainal, S. (2010). Is Entrepreneurial Competency the Silver Bullet for SME Success in a Development Nation? International Business Management , 4 (2), 6775.

Buckingham, M., \& Clifton., D. (2001). Ahora, Descubra sus Fortalezas. (A. De Hassan, trad.). Bogotá: Grupo Editorial Norma.

Chen, M. (2007). Entrepreneurial leadership and new ventures: Creativity on entrepreneurial teams. Creativity and Innovation Management , 16 (3), 239-249. 
Covey, S. R. (1997). Los Siete Hábitos de la Gente Altamente Efectiva. La Revolución Ética en la Vida Cotidiana y en la Empresa. (J. Pistigorky, translator.). México D.F.: Paidós Mexicana, S.A.

Covin, J., \& Slevin, D. (1991). A conceptual model of entrepreneurship as firm behavior. Entrepreneurship Theory and Practice, 16 (1), 7-25.

Dhanak, M. S. (2017). Concept of Entrepreneur ,Entrepreneurship. Retrieved Jan 23, 2017, from Scribd Inc: http//:scribdinc.com

El Shenawy, E., Baker, T., \& Lemak, D. (2007). A meta-analysis of the effect of TQM on competitive advantage. Int. J. Qual. Rel. Manag , 24 (5), 442-471.

Escrig-Tena, A. (2004). TQM as a competitive factor: A theoretical and Empirical Analysis. Int. J. Qual. Rel. Manag, 21 (6), 612-637.

Evangelista, R. (2013, Nov 15). Entrepreneurship in the Philippines: Opportunities and challenges for inclusive growth. Center for Institutiona Private Enterprizes .

Forces, Porter's Five. (2010, Mar 23). A Definition of Entrepreneurship. Retrieved Jan 23, 2017, from Qucik MBA Knoweldge to power of business: http://www.QuickMBA.com/

Fuentes, M., Montes, F., \& Fernández, L. (2006). Total quality management, strategic orientation and organizational performance: the case of Spanish companies". Total Quality Management, 17 (13).

Ganeshan, G. (2001). Entrepreneurship Development. Kisan World , 28 ( 6), 50-51.

Ghosh, B. (2017, Jan 20). Entrepreneur. Retrieved Feb 5, 2017, from KNOWSTARTUP INSPIRING ENTREPRENEURS: http://knowstartup.com/

Gilbert, G. (1992). Quality Improvement in a Defense Organization. Public Productivity and Management Review , 16 (1), 65-75.

Goswami, A., Dalmia, N., \& Pradhan, M. (2008). Entrepreneurship in India. India: National Knowledge Commission.

Gupta, V., MacMillan, I., \& Surie, G. (2004). Entrepreneurial leadership: Developing and measuring a cross-cultural construct. Journal of Business Venturing , 19 (2), 241-260.

Han, S. B., Chen, S. K., \& Ebrahimpour, M. (2007). "The Impact of ISO 9000 on TQM and Business Performance". The Journal of Business and Economic Studies , 13 (1), 1- 25.

Kaynak, H. (2003). The relationship between total quality management practices and their effects on firm performance. J. Oper. Manag., , 21, 405-435.

Kuratko, D. (2007). Entrepreneurial leadership in the 21st century. Journal of Leadership and Organizational Studies , 13 (4), 1-11.

Lenka, U., \& Suar, D. (2008). A holistic model of total quality management in services". The Journal of Management Research , 7 (3), 56-72.

Rae, D. (2007). Connecting enterprise and graduate employability: Challenges to the higher education culture and curriculum? Education + Training , 49 (8/9), 605-619.

Reed, R., Lemak, D., \& Mero, N. (2000). Total Quality Management and sustainable competitive advantage. J. Qual. Manag , 5, 5-26. 
Sila, I., \& Ebrahimpour, M. (2000). An investigation of the total quality management survey based research published between 1989 and 2000: A literature review. Int. J. Qual. Rel. Manag, 19 (7), 902-970.

Wikipedia, free encyclopedia. (2017, Jan 16). Entrepreneurship. Retrieved Jan 23, 2017, from Wikipedia, free encyclopedia: http:///C:/Users/Dell/Downloads/Entrepreneurship\%20$\%$ 20Wikipedia.htm

Zahra, S. (1991). Predictors and Financial Outcomes of Corporate Entrepreneurship: an Exploratory Study. J. Bus. Venturing, 6, 245-254.

Zahra, S., Nielsen, A., \& Bonger, W. (1999). Corporate entrepreneurship, Knowledge, and Competence Development. Entrep. Theory Pract , 23 (3), 169-183. 